\title{
The Correlation Between Physical Activity and Academic Motivation of Undergraduate Medical Students of the Universitas Islam Indonesia
}

\author{
Syafira Laila Nurulita ${ }^{1, *}$, Yanasta Yudo Pratama ${ }^{2}$, Hafidhania Penadi $^{1}$, Irsalina Nur \\ Timami $^{1}$, Alfia Qurrota Ayun ${ }^{1}$, Umatul Khoiriyah ${ }^{1}$ \\ ${ }^{1}$ Universitas Islam Indonesia \\ ${ }^{2}$ Universitas Gadjah Mada \\ ${ }^{*}$ Corresponding author. Email: 18711008@students.uii.ac.id
}

\begin{abstract}
Background: The Covid-19 pandemic has caused changes in activity. Changing physical activity can cause various psychological changes in humans. For medical students, psychological changes because physical activity is an important factor in supporting academic motivation to learn. This study was aimed to examine the correlation between physical activity and academic motivation of undergraduate medical students at the Universitas Islam Indonesia during the pandemic.

Methods: This study was an observational study using a cross-sectional method with a sample of undergraduate medical students at the Universitas Islam Indonesia. Data was collected through an e-questionnaire. Physical activity was measured by the International Physical Activity Questionnaire (IPAQ), and Academic Motivation was measured by the Intrinsic Motivation to Know (IMTK), which is part of the Academic Motivation Scale (AMS). Subjects were selected through consecutive sampling methods and followed the inclusion and exclusion criteria. After the main test was carried out, statistical analysis was then conducted.

Results: Data analysis using the Kolmogorov-Smirnov normality test with two variables (physical activity and academic motivation) obtained $\mathrm{p}<0.05$. The Spearman test showed non-significant results with $p>0.05$ Conclusion: This study shows that there is no relationship between physical activity and academic motivation of Undergraduate Medical Students of the Universitas Islam Indonesia during the Pandemic.
\end{abstract}

Keywords: Academic Motivation, Pandemic, Physical Activity.

\section{INTRODUCTION}

On January 31, 2020, the World Health Organization (WHO) declared the Covid-19 virus outbreak to have an emergency status and became a health problem worldwide [1]. COVID-19 cases continue to increase and reached $114,379,825$ total cases in the world on February 28,2021 [2]. Indonesia is ranked 18th worldwide with total cases of $1,329,074$ and a total mortality rate of 35,981 people [2]. COVID-19 is an infectious disease caused by severe acute respiratory syndrome coronavirus 2 or SARS-CoV-2 [3]. Symptoms experienced in sufferers of Covid-19 can include coughing, shortness of breath or difficulty breathing, fever or chills, muscle or body aches, vomiting or diarrhea, the new loss of taste or smell [4]. The condition is severe and requires medical attention if it occurs, trouble breathing, persistent pain or pressure in the chest, new confusion, inability to wake or stay awake, bluish lips or face [4].

Handling of Covid with Work From Home (WFH) due to the fast spread, the public is advised to reduce outdoor activities and stay home [5]. The government has also implemented physical distancing to reduce the number of new cases. This causes a large number of people to work from home or school online so that people spend more time at home [5]. In Indonesia, as of March 18, 2020, as many as 276 universities, state and private sectors in Indonesia have applied online lectures [6]. The application of physical distancing causes physical 
activity that can be done for health, such as decreased sports [5].

Physical activity is defined as any form of body movement that is produced by the skeletal muscles and produces significant energy expenditure and is divided into light, moderate and heavy groups. Every activity requires different energy depending on the length of the intensity and the muscle's work [7]. During the Covid-19 pandemic, some people only spent time at home, such as working and studying virtually. This also made it difficult to exercise for several reasons. During a pandemic, physical activity is necessary for people of all ages. Performing physical movements during work from home with light intensity for 3-4 minutes, such as walking or stretching, can help relax muscles and improve blood circulation and muscle activity [8]

Pandemics can affect individual and community psychology, such as causing disorders, anxiety, stress, stigma, and xenophobia [9]. In students, psychological changes during a pandemic are related to the fact that university closure and online media use as learning can affect daily activities that can impact psychological change [10]. Other psychological factors include the motivation to learn to achieve a specific goal [11]. Motivation is a human psychological characteristic that contributes to a person's level of commitment, including the factors that cause, channel and maintain the behavior in a certain direction of determination [12].

Motivation to learn is divided into two aspects, namely intrinsic and extrinsic. Intrinsic motivation is divided into three aspects, one of which is intrinsic motivation to know. Intrinsic motivation to know is the motivation that refers to pleasure and satisfaction in carrying out activities that learn, explore and understand something new [13]. In medical students, motivation is important for student performance because the medical education program is very intensive. For example, medical students must participate in clinical activities and lecture activities [14].

Therefore, this study was aimed to know the correlation between physical activity and academic motivation of undergraduate medical students at the Universitas Islam Indonesia during the Covid-19 pandemic.

\section{METHOD}

This study was an observational study using a crosssectional method with undergraduate medical students as subjects at the Universitas Islam Indonesia. Data was collected through an e-questionnaire. Physical activity is measured by the International Physical Activity Questionnaire (IPAQ) [15]. Academic Motivation is measured by the Intrinsic Motivation to Know (IMTK), which is part of the Academic Motivation Scale (AMS) [13].

Subjects were 166 students selected through consecutive sampling methods and followed the inclusion criteria: 1.) Undergraduate students of the Faculty of Medicine, Universitas Islam Indonesia, 2.) willing to participate in research by filling out a questionnaire. The exclusion criteria were students with chronic diseases.

After the test was carried out, statistical analysis was then carried out. The first data analysis was performed using the univariate descriptive. After the univariate descriptive analysis was carried out, the correlation test was then conducted. However, before doing the correlation test, the normality test is conducted first to determine the normality of the data distribution so that it can determine the appropriate correlation test. The data normality test was carried out using the KolmogorovSmirnov test because the data amounted to 116 (>50). The Kolmogorov-Smirnov test will get results that are said to be normal if $p>0.05$. In this study, the data distribution is not normal ( $\mathrm{p}<0.05)$, a correlation test is performed using Spearman's correlation test. The results will be assessed as having a statistically significant correlation if $\mathrm{p}<0.05$.

\section{RESULT}

The Kolmogorov-Smirnov normality shows $\mathrm{p}=0.00$ ( $p<0.05)$ so the data distribution is not normal. The Correlation analysis uses Spearman's test, and the results are in Table 1. The Spearman's correlation test is said to have a statistically significant relationship if the result is $p<0.05$. In the test conducted in this study, the result was $p=0.086(p>0.05)$, which means it is not significant.

Table 1. Correlation Test Results with the Spearman test

\begin{tabular}{|l|l|l|l|l|}
\hline \multicolumn{2}{|c|}{} & $\begin{array}{l}\text { IPAQ } \\
\text { Score }\end{array}$ & $\begin{array}{l}\text { IMTK } \\
\text { Score }\end{array}$ \\
\cline { 4 - 5 } & & \\
\hline \multirow{2}{*}{$\begin{array}{l}\text { Spear } \\
\text { man's } \\
\text { rho }\end{array}$} & $\begin{array}{l}\text { IPAQ } \\
\text { Score }\end{array}$ & $\begin{array}{l}\text { Correlation } \\
\text { Coefficient }\end{array}$ & 1.000 & 0.134 \\
\cline { 2 - 5 } & & Sig.(2-tailed) & & 0.086 \\
\cline { 2 - 5 } & $\begin{array}{l}\text { IMTK } \\
\text { Score }\end{array}$ & $\begin{array}{l}\text { Correlation } \\
\text { Coefficient }\end{array}$ & 0.134 & 1.000 \\
\cline { 2 - 5 } & & Sig.(2-tailed) & 0.086 & \\
\hline
\end{tabular}




\section{DISCUSSION}

A total of 166 medical student data obtained using the IPAQ questionnaire. Descriptive Univariate Analysis is done by categorizing scores based on criteria Category: 1.) Mild: <600 MET/week 2.) Moderate: 600-1500 MET/week and 3.) Height:> $1500 \mathrm{MET} /$ week results obtained in Table 2. That there are $115(69 \%)$ medical students with mild activity and $51(31 \%)$ with moderate activity during the Covid-19 pandemic.

\begin{tabular}{llc}
\hline & \multicolumn{2}{c}{ IPAQ Score } \\
\cline { 2 - 3 } Category & $\mathrm{N}$ & $\%$ \\
\hline Mild & 51 & 31 \\
Moderate & 115 & 69
\end{tabular}

Table 2 Level of Physical Activity at undergraduate medical students at the Universitas Islam Indonesia

While the univariate descriptive analysis carried out on Intrinsic Motivation To Know with category criteria: 1.) low: <13 2.) moderate: $13-20$ and 3.) high:> 20, the results are shown in Table 3 That there are 7 (4\%) with low, 7 (4\%) moderate and 152 (92\%) high intrinsic motivation to know medical students.

\begin{tabular}{llc}
\hline & \multicolumn{2}{c}{ IPAQ Score } \\
\cline { 2 - 3 } Category & $\mathrm{N}$ & $\%$ \\
\hline Low & 7 & 4 \\
Moderate & 7 & 4 \\
High & 152 & 92
\end{tabular}

Table 3 Intrinsic Motivation to know the level of undergraduate medical students at the Universitas Islam Indonesia.

This study shows that the non-significant relationship between physical activity and academic motivation is not in line with research conducted by Riyanto \& Mudian (2019), which shows a significant relationship between physical activity and emotional intelligence in students [16]. Then research conducted by Chandra (2017) shows a significant relationship between emotional intelligence and academic motivation in students [17].

Another study conducted by Al-Drees et al. (2016) showed a positive relationship between physical activity and academic achievement in medical students [18]. Another study conducted by Sivrikaya (2019) states that academic motivation is related to student learning achievement [19].
The discrepancies in the results of this study may occur due to differences in the population studied. The sample used is relatively small. A cross-sectional study design can be a limit to this research.

\section{CONCLUSION}

This study shows that there is no significant relationship between physical activity and academic motivation of Undergraduate Medical Students of the Universitas Islam Indonesia during the Covid-19 pandemic.

\section{AUTHORS' CONTRIBUTIONS}

SLN \& YYP is used to design studies and analyze data. While HP, INT \& AQA is used to collect data. The UK contributes to designing data and compiling reports.

\section{ACKNOWLEDGMENTS}

The authors wish to thank all undergraduate medical students at Universitas Islam Indonesia who participated and completed the questionnaire.

\section{REFERENCES}

[1] WHO. Epi-Win-Update40-Overview-of-thePandemic. Coronavirus Updat 40-World Heal Organ [Internet]. 2020;33. Available from: https://www.who.int/docs/defaultsource/coronaviruse/risk-comms-updates/epi-winupdate40-overview-of-thepandemic.pdf?sfvrsn $=8 \mathrm{~d} 355 \mathrm{bcd} \_4$

[2] Worldometer. Coronavirus Update (Live): Cases and Deaths from COVID-19 Virus Pandemic [Internet]. Worldometers. 2021. p. 1. Available from: https://www.worldometers.info/coronavirus

[3] Fitria L, Ifdil I. Kecemasan remaja pada masa pandemi Covid -19. J Educ J Pendidik Indones. 2020;6(1):1.

[4] CDC. Symptoms of Coronavirus (COVID-19). Cdc [Internet]. 2020;317142. Available from: https://www.cdc.gov/coronavirus/2019ncov/symptoms-testing/symptoms.html

[5] Nurhadi JZL, Fatahillah. Pengaruh Pandemi Covid19 Terhadap Tingkat Aktivitas Fisik Pada Masyarakat Komplek Pratama, Kelurahan Medan Tembung. J Heal Sains. 2020;1(5):294-8.

[6] Arifa FN. Tantangan Pelaksanaan Kebijakan Belajar Dari Rumah Dalam Masa Darurat Covid19. Info Singkat;Kajian Singk Terhadap Isu Aktual Dan Strateg [Internet]. 2020;XII(7/I):6. Available from: 
http://berkas.dpr.go.id/puslit/files/info_singkat/Inf o Singkat-XII-7-I-P3DI-April-2020-1953.pdf

[7] Habut YM, Nurmawan SP, Wiryanthini DAI. Relationship of Body Mass Index and Physical Activity for Dynamic Balance. Maj Ilm Fisioter Indones. 2018;2:45-51.

[8] Muralidar S, Visaga S, Sekaran S. Since January 2020 Elsevier has created a COVID-19 resource centre with free information in English and Mandarin on the novel coronavirus COVID- 19 . The COVID-19 resource centre is hosted on Elsevier Connect , the company' s public news and information . 2020;(January).

[9] Javed B, Sarwer A, Soto EB, Mashwani Z ur R. The coronavirus (COVID-19) pandemic's impact on mental health. Int $\mathrm{J}$ Health Plann Manage. 2020;35(5):993-6.

[10] Pedrosa AL, Bitencourt L, Fróes ACF, Cazumbá MLB, Campos RGB, de Brito SBCS, et al. Emotional, Behavioral, and Psychological Impact of the COVID-19 Pandemic. Front Psychol. 2020;11(October):1-18

[11] Sulfemi WB. Hubungan Motivasi Belajar Dengan Hasil Belajar Ips Di Smp Kabupaten Bogor. Edutecno. 2018;18(106):1-12.

[12] Umboh E, Kepel B, Hamel R. Hubungan Antara Motivasi Belajar Dengan Prestasi Akademik Pada Mahasiswa Program Studi Ilmu Keperawatan Fakultas Kedokteran Universitas Sam Ratulangi Manado. J Keperawatan UNSRAT. 2017;5(1):108275.

[13] Marvianto RD, Widhiarso W. Adaptasi Academic Motivation Scale (AMS) versi Bahasa Indonesia. Gadjah Mada J Psychol. 2019;4(1):87.

[14] Wu H, Li S, Zheng J, Guo J. Medical students' motivation and academic performance: the mediating roles of self-efficacy and learning engagement. Med Educ Online [Internet]. 2020;25(1):1-9. Available from: https://doi.org/10.1080/10872981.2020.1742964

[15] Purnama H, Suhada T. Tingkat Aktivitas Fisik Pada Lansia Di Provinsi Jawa Barat, Indonesia. J Keperawatan Komprehensif. 2019;5(2):102.

[16] Riyanto P, Mudian D. Pengaruh Aktivitas Fisik Terhadap Peningkatan Kecerdasan Emosi Siswa. J Sport Area. 2019;4(2):339-47.

[17] Chandra A. Hubungan Antara Kecerdasan Emosional Dengan Motivasi Belajar Pada Mahasiswa. J Psikol Konseling. 2017;10(1):1-10.
[18] Al-Drees A, Abdulghani H, Irshad M, Baqays AA, Al-Zhrani AA, Alshammari SA, et al. Physical activity and academic achievement among the medical students: A cross-sectional study. Med Teach. 2016;38(March):S66-72.

[19] Sivrikaya AH. The Relationship between Academic Motivation and Academic Achievement of the Students. Asian J Educ Train. 2019;5(2):309-15. 